\title{
Proximate, Anti - Nutrients and Sensorial Acceptability of Some Cereal and Legume Based Composite Biscuits: Review
}

\author{
Milkesa Feyera \\ Melkassa Agricultural Research, P.O.BOX 436, Adama, Ethiopia
}

\begin{abstract}
The major determinants of malnutrition in Africa are low availability of nutritious foods and inadequate consumption of protein-rich diets. Consumption of nutritious snacks could help to reduce protein-energy malnutrition in children and adults. Biscuits are a ready-to-eat, convenient and cheap snack that is consumed by all age group in many countries. It can be produced from cereal and legume flour blends. A proximate composition such as protein, ash, crude fiber, and fat content of some cereal-legume based biscuit increased with increase in the percentage substitution of legumes flour. Carbohydrate content of biscuits decreased as legume substitution increased. The Ash (total mineral) content of some cereal and legume-based biscuits increased as the level of legume flour incorporation increased. The increased in some nutrient composition of the biscuit in cereal and legume blends could be due to the significant quantity of nutrients in legumes. Anti-nutritional factors (ANF) such as tannin and phytic acid affect digestibility and nutrient bioavailability for absorption. Substitution of malted cereal flour with legume flour resulted decreased in the level of both tannin and phytate in the composite biscuits and vice versa. Lower tannin and phytate content observed could be due to degradation of tannin and phytate during malting. Sensory attributes such as color, texture, aroma, taste, and overall acceptability of some cereal and legume-based biscuits were highly rated (in acceptable ranges).
\end{abstract}

Keywords: Nutrient composition, Cereal, Anti-nutritional factors, Biscuits, Legume, Sensory acceptability, composite flour

DOI: $10.7176 / \mathrm{FSQM} / 98-03$

Publication date: June $30^{\text {th }} 2020$

\section{INTRODUCTION}

Biscuits are ready-to-eat, convenient and cheap snack that are consumed by all age group in many countries (Adebowale et al., 2012). In baking industry wheat is widely preferred cereal and most commonly used in biscuit production because of its unique rheological properties imparting positive effect on baking quality (Svec and Hruskova, 2010). Most of these foods made from wheat and other cereals are, however, poor sources of protein that is often of poor nutritional quality (Alobo, 2001). Enrichment of cereal- based foods with other protein sources such as oil seeds and legumes has received considerable attention (Dhingra and Jood, 2000). This is because of oil seed and legumes are rich in proteins particularly essential amino acid which are limited in most cereals. The use of composite flour based on wheat and other cereals in bakery products are becoming popular because of the economic and nutritional advantages of composite flour (Neelam et al., 2009).

Cereals and legumes reside a significant position in human nutrition particularly in the dietary pattern of low economic population from developing countries are said to be the best combination for delivering good nutrients. Cereal is a staple food crop on which the lives of millions of people depend. In Ethiopia cereals like maize, wheat, barley, sorghum, millet, etc are among the most important crops in terms of cultivated area coverage and in total grain production (CSA, 2015). They are a good source of energy, proteins, carbohydrates, vitamins and minerals including the trace elements, particularly iron and zinc. Cereal contains minerals such as phosphorus, calcium, potassium and magnesium in varying quantities (Dicko et al., 2006). Foods prepared from whole cereals contain increased concentration of phytochemicals along with other vitamins and minerals (Slavin, 1999)

The major determinants of malnutrition in Africa are low availability of nutritious foods and inadequate consumption of protein rich diets. Animal foods are generally good sources of protein, but are not affordable by the poor communities and thus leaving foods of plant origin as an important source of protein in developing countries. Consumption of nutritious snacks could help to reduce protein-energy malnutrition in school children and adults (Abioye et al., 2016). Like cereals, legumes which are considered as poor man's meat are also excellent sources of dietary complex carbohydrates (starch and dietary fiber), protein, minerals and B vitamins (Tharanathan and Mahadevamma, 2003). In Ethiopia legumes such as soyabean, mung bean, chickpea, cowpea, haricot bean and lentils are cultivated mostly in high and low land areas of Oromiya, Amhara, Benishengul Gumuz, and SNNPR Regional states (CSA, 2015). The legumes that are generally consumed by the people contain low fat, high protein, dietary fiber and good amount of micronutrients and phytochemicals (Messina, 1999). Though the cereals and legumes are unique in their individual nutrient composition, health benefits and other functional properties. Cereals are poor source of the essential amino acid like lysine which is abundant in pulses. On the other hand, methionine is complemented by cereal protein which is less in legume (Iqbal et al., 2006). Hence, the overall protein quality, nutritional value and health promotion further more increases when cereals and legumes are combined together as 
composite mix. Legumes are one of such plant protein source, which used partially to complement cereal in the production of bakery products such as biscuits, bread or other confectionery could go a long way in improving the nutritional quality of such products. Attempts have been made to fortify cereals with legumes to make nutritionally superior and acceptable products ( Ayo et al., 2014).

Biscuits have been produced from mixture of different flours of cereals and legume or root crops which is known as composite flour so as to satisfy specific functional characteristics and nutrients composition (Ubbor and Akobundu, 2009). However, it has continued to be poor digestibility and nutrient bio availability for absorption. This is largely due to the presence of anti-nutritional factors (ANF) such as tannin and phytic acid . Traditional processing techniques like malting has the potential for anti nutrient reduction in various grains. Different malting duration applied to cereals and legumes cultivars brought significant reduction in both phytic and tannin contents (Maidala et al., 2016). Malting also caused an improvement in protein digestibility and other protein quality characteristics, such as percentage of protein, nitrogen solubility index and content of an essential amino acid, lysine with increasing time (Dewar et al., 1997). Therefore the aim of this seminar paper is to review the nutritional composition, anti-nutritional factors and organoleptic acceptability of biscuits produced from some cereals and legumes composite flour.

\section{Health Benefits of Cereals and Legumes}

Whole cereals and legumes occupies vital function in the avoidance of chronic diseases. People who consume whole cereals and legumes had shown better nutritional status and health benefits (Cleaveland et al., 2000). Consumption of some cereals and legumes based biscuits cause the reduction of the degenerative diseases. Hence the usage of cereals and legumes in different proportions in the product will provide good nutrition. According to Itagi (2012) consumption of whole cereals has increased concentration of dietary resistant starch, fiber and oligosaccharides. They also contain antioxidant which includes minerals and phenolic compounds which play vital role in prevention of various diseases. Legumes are rich and efficient source of protein, complex carbohydrates (dietary fiber), minerals and vitamin while cereal grains provide important amount of proteins, carbohydrates and selected micronutrients (Salunke et al., 2005).

Cereals and legumes provide positive health responses when they are properly positioned in the daily diet (Kushi et al., 1999). In addition, work carried out by Kaur et al. (2011) revealed associations between the utilization of legumes and declining prevalence of numerous diseases for examples aging, cancer, diabetes and cardiovascular diseases. Intake of whole grain will protect against cancer, cardio vascular disease, diabetes and obesity because of the phytochemicals present in it. Cereal fibers has consistently lowered the risk of diabetes and helpful in the management of people who have already developed type 2 diabetes mellitus (Willet et al., 2002). The resistant starch content present in the legume and their low starch digestion rate released the glucose into the blood stream in slow rate, which resulted in reduced glycemic index in comparison with other foods (Tovar et al., 1992). The resistant starches are probiotic and act as a substrate for microbiological fermentation (Machado et al., 2008). Intake of diet high in whole cereals showed a positive association with lower body mass index, eventually a decrease in waist circumference and reduced risk of being overweight (Biglari et al., 2008). Legumes have shown positive contribution to weight control due to the comparative low glycemic index and high resistant starch. The water soluble dietary fibers present in oats shows significant result in reduction of blood cholesterol which in turn reduced the risk of high blood pressure ( Filipcev et al., 2011).

\section{Biscuit Production Technology}

Among ready-to-eat snacks, biscuits possess several attractive features including wider consumption base, relatively long shelf-life, more convenience and good eating quality (Hooda and Jood, 2005). Long shelf-life of biscuits makes large scale production and distribution possible. Good eating quality makes biscuits attractive for protein fortification and other nutritional improvements. The term biscuits as they are called in many parts of the world, refers to a baked product generally containing the three major ingredients; flour, sugar and fat. Biscuit is a low moisture bakery product.

According to the information provided by various manufacturers, its moisture content varies widely, because of the variation in its thickness and weight during forming and shaping. Typically, the moisture content of biscuit after baking is below 10\%. For sweet biscuit that contains high levels of sugar and fat, the dough has good cohesiveness and plasticity without the formation of a gluten network. They also reported that replacing part of wheat flour with rice flour and soy flour enhanced the nutritive value due to the complementary nature of the amino acids in these raw materials. According to Taha et al. (2006) study fortification of biscuits with broad bean, chickpea flour, or isolated soy protein were produce high-protein biscuits with consumer acceptance.

Biscuit can be produced following standard methods. using the creaming method described by Okaka ( 1997) was one of the standard biscuit production procedure applied widely for cereal- legume based biscuits. The basic ingredient used for biscuit production were composite flour (100\%), fat (40\%), sucrose (60\%), milk (4\%), salt $(2 \%)$ and baking powder $(1 \%)$. The sugar and fat were initially creamed in a mixer to produce a creamy mixture 
before the flour and other dry ingredients were added. There after, the mixture was thoroughly mixed to form hard consistent dough. The dough obtained then thoroughly kneaded manually on a smooth clean table for about 5 mins. The dough thinly rolled on a wooden board with rolling pin to uniform thickness $(2 \mathrm{~mm})$ and cut out (using biscuit cutter) to desired shapes of similar sizes. The cut out biscuit dough pieces were placed in a greased baking tray and baked in an oven at $200^{\circ} \mathrm{C}$ for 20 mins to produce biscuits. The biscuits then allowed to cooled for 15 minutes and packed in polyethylene bags, sealed and kept at desired temperature. For brief expression biscuit production flow chart are represented below.

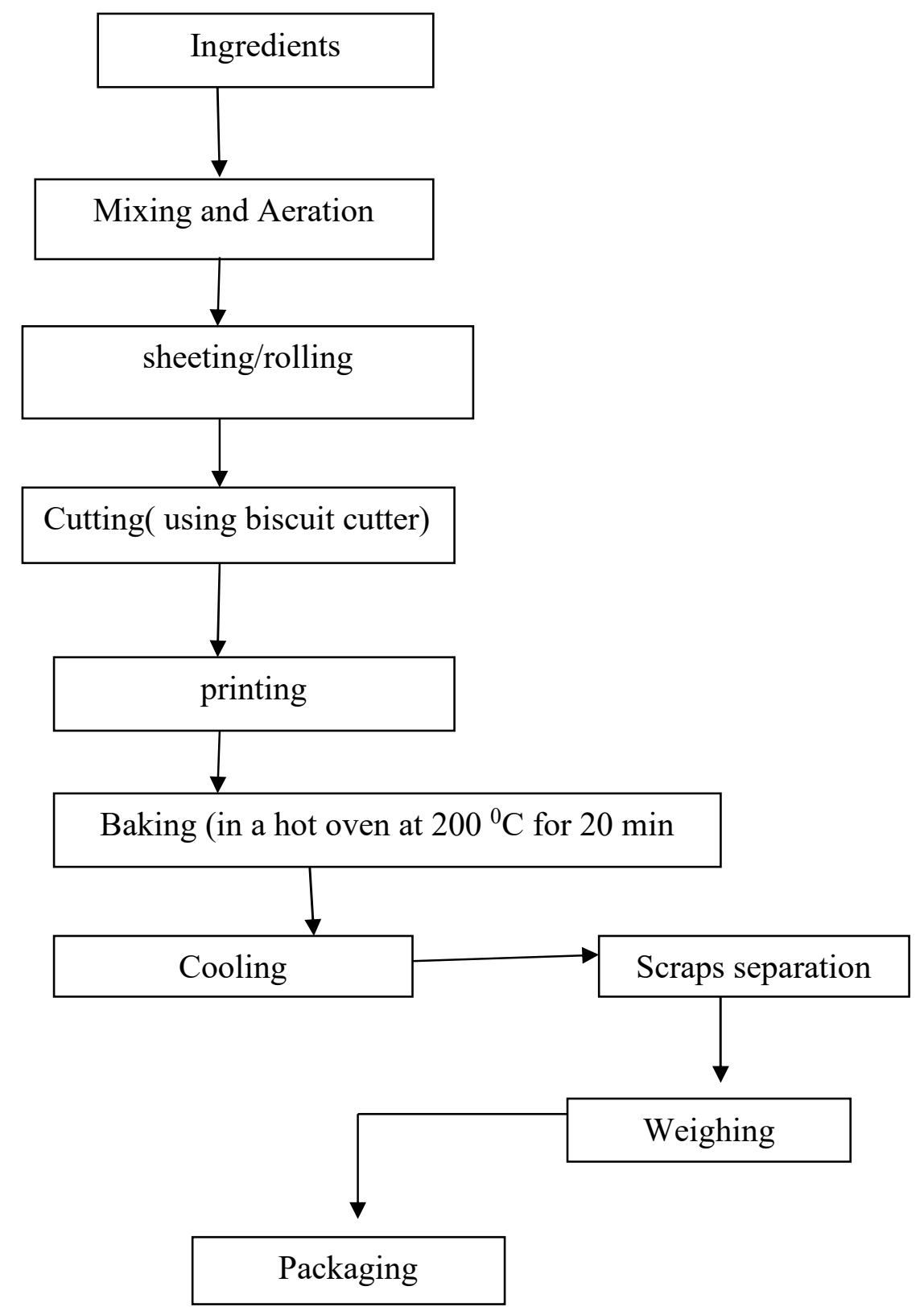

Figure 1: Flow Chart for the Production of Biscuits

\section{Malting Technique for Anti Nutrient Reduction}

Malting involves germination and sprouting of grain. During the process the seeds are soaked in water to hydrate the grain and a number of complex chemical reaction are activated (Brigas et al., 2003). It is effective processing techniques to enhance the nutritional status of both cereal and legume based food. Malting caused an improvement in protein digestibility and other protein quality characteristics, such as percentage of protein, nitrogen solubility index and content of an essential amino acid, and lysine (Dewar et al., 1997).

Malting has produced improvement in flavor profile and color (Rooney and Waniska, 2000). It has the potential for anti nutrient reduction in various grains. Malting of Kaura sorghum for 48 hours reduced $(96.33 \%)$ of tannin, (80.29\%) of phytate acid and $(86.67 \%)$ oxalate and depressed most of the tannin factors (Maidala et al., 
2016). Reduction in tannin is brought about by leaching as reported by Sandberg, (2002; Ugwu and Oranye, (2006). According to Idris et al. ( 2007) activity of phytase enzyme, reduce of phytate is by degrading of phytate into inorganic phosphorus and myo inositol and its intermediate forms. The process of malting comprises three unit operations: steeping, germination, and drying. During steeping, kernels are immersed in water until imbibed with sufficient water to start the metabolic processes of germination and at the same time dirt, chaff and broken kernels are removed by washing and flotation. The germination phase begins after the kernels have absorbed enough water to start enzyme production and starch hydrolysis.

Conditions that are necessary during the germination phase are moisture content, temperature, length of germination time, and oxygen availability. Germination takes about 4-6 days and occurs rapidly between $20^{\circ} \mathrm{C}$ and $30^{\circ} \mathrm{C}$ with an optimum temperature of $25^{\circ} \mathrm{C}$ to $28^{\circ} \mathrm{C}$. The most important physiological processes associated with the germination phase are the synthesis of amylases, proteases and other endogenous hydrolytic enzymes. During the process, the hydrolytic enzymes migrate from the germ into the endosperm where starch and protein are hydrolyzed to sugars and amino acids respectively. These are then transported into the germ where they are further metabolized by the growing seedling (Hoseney, 1994).

Drying is the final stage of the malting process and is required for stopping further growth of the kernels, reducing the moisture content and water activity, hence producing a shelf-stable product. Kernels are dried at a temperature of about $50^{\circ} \mathrm{C}$ for 24 hours. After drying the roots and shoots are removed and the kernels milled into malted flour ready for use in the preparations of different food products (Hoseney, 1994).

\section{Nutrient Composition of Composite Biscuits Protein}

Protein is essential components of the diet needed for the survival of humans and animals. It is one of the most essential and multi-purpose nutrient, as it supply adequate amounts of essential amino acids that had a wide variety of physiological functions associated with optimal physical performance and wellbeing (Andersen et al., 2005). The protein nutritional quality of a food depends on content, digestion, absorption and utilization of amino acids. Protein content of composite biscuits made from mung bean and wheat flour was increased as the level of mung bean complementation increased (Akaerue and Onwuka., 2010). According to finding of Bolarinwa et al. (2016) the protein content of the biscuit made from malted sorghum-soy samples ranges from $7.28 \%$ to $11.74 \%$. Similar works reported by Adebowale et al.(2012) is showed that the protein content of sorghum-wheat composite flour biscuits ranges from $7.06 \%$ to $11.84 \%$.

The protein content of the malted sorghum-soy biscuit is higher than that of conventional wheat biscuit (100\% wheat biscuit). This could be due to significant quantity of protein in soyabean. Protein content of biscuit produced from local rice variety and defatted soyabean blends $(16.50 \%-20.21 \%)$ also increased as the level of defatted soyabean incorporation increased (Eke- Ejiofor and Williams, 2016). An improved nutritional content of biscuits have been produced from African yam bean flour, wheat composite flour. Protein content of African yam bean flour and wheat composite biscuits were increased as the incorporation level of African yam bean flour increased (Idowu, 2014). Protein composition of biscuit formulated from millet and cowpea was also increased as the level of cowpea increased (Hama et al., 2018). The other research report also indicated that protein content of biscuits $19.33 \%$ was obtained from $40 \%$ of lima bean, $25 \%$ sorghum and $35 \%$ of wheat composite flour (Adebayo, 2017). The protein content of the some cereal and legume based biscuits increased with increasing in the percentage substitution of legume flour in the biscuit dough blends. The increased in the protein content of some cereal and legume based biscuits could be due to the significant quantity of protein in legume seeds ( Sanfu et al., 2010). Legumes have been reported to be a good source of cheap protein (Ward law et al., 2004). Ayo et al. (2014) also reported that the protein content (5.26-11.65\%) of malted soybean-acha biscuits increased by substituting malted soybean flour with acha flour. Therefore legumes are promising nutritious grain to be used in development of value added food product which is adequate in protein content through blending with cereals. Regular consumption of cereals -legumes biscuits by children and adults could help to increase their protein intake.

\section{Crude Fat}

Fats (or lipids) serve a variety of functions, including all three purposes of nutrition: to form and maintain body structures, to regulate metabolism, and to provide the second main source of energy. Fats provide $40-45 \%$ of the total daily energy intake in sedentary people living in industrialised countries (Thompson et al., 2004). Fat content of the composite flour ranged depend on the type of ingredient used for composite flour production. The fat content of the composite flour will increased with increasing substitution with soy flour. Malted sorghum with $40 \%$ soy flour blend had the fat content $(9.26 \%)$ while the fat value $(2.49 \%)$ was observed in $100 \%$ malted sorghum flour (Bolarinwa et al., 2016).

The fat content of the sorghum and soyabean based composite biscuit was relatively high when un-deffated soy flour was used for the mixes. Alabi et al. (2007) also reported that sorghum soy composite biscuits contain $(3.6 \%)$ of fat. The other similar study reported by Falola et al. (2013) indicated that the fat content of rice and 
soyabean blends increased as soy flour proportion increased. Similar research report indicated that fat content of biscuit produced from local rice variety and defatted soyabean blends decreased as the level of rice incorporation increased (Eke- Ejiofor, J. and Williams, 2016). Similarly as the other some cereal and legume based biscuits, the fat composition of biscuit formulated from millet and cowpea was also increased as the level of cowpea complementation increased (Hama et al., 2018). Fat content of biscuits produced from lima bean, sorghum and wheat composite flour was ranged from 4.32 - 4.87 (Adebayo, 2017). In contrast to soyabean incorporation to cereal, the fat content of biscuit produced from wheat and African yam bean blends reduced (12.53-8.13) as the level of African yam bean flour increased (Idowu, 2014). The decreased obtained in the fat contents of the biscuit samples may be attributed to the fact that African yam bean flour has been observed to contain low values of crude fat (Eneche, 2003). This makes composite biscuit from AYBF desirable because of the low fat and the fact that low fat food products are less susceptible to rancidity and hence, more shelf stable.

\section{Crude fiber}

Dietary fiber is defined as lignin plus the polysaccharide components of plants which are indigestible by enzymes in the human gastrointestinal tract (Bermink, 1994). These components are typically divided into two categories. Soluble dietary fiber is those components that are soluble in water and includes pectic substances and hydrocolloids. Insoluble dietary fiber is those components that are insoluble in water and includes cellulose, hemicelluloses and lignin. Consumption of dietary fiber has numerous benefits in protection against heart disease and cancer, normalization of blood lipids, regulation of glucose absorption and insulin secretion and prevention of constipation and diverticulitis disease ( Rave et al., 2007).

Cereal and legume have good source of fiber and their content is varied from one crop to another. The crude fibre of the malted sorghum and soyabean biscuit samples ranged between 2.56 to $3.46 \%$ while that of wheat biscuit is $3.54 \%$. The increment in the crude fibre content of the biscuits could be due to the hydrolysis of fibre during malting process. Malted sorghum has been reported to contain low levels of crude fibre (Germah et al., 2011). Fiber content of biscuit produced from local rice variety and defatted soyabean blends decreased as the level of rice incorporation increased (Eke- Ejiofor, J. and Williams, 2016). This could be due to low crude fiber contents in rice. Fiber content of African yam bean flour and wheat composite biscuits were decreased as the incorporation level of African yam bean flour increased (Idowu, 2014). According to Adebayo (2017) fiber content of biscuits prepared from composite flour of lima bean, sorghum and wheat composite flour was increased as the proportion of lima bean reduced. Crude fiber composition of biscuit formulated from ingredients of millet and cowpea was increased as the level of millet increased (Hama et al., 2018). The crude fibre content reported by Ayo et al. (2014) of malted soybean-acha biscuit was 1.12-1.40\%. High fibre foods are reported to enhance gastrointestinal tract functions (Schneeman, 2002). The related research report indicated that crude fibres content was not significantly better than each other for biscuit produced from lima bean, sorghum and wheat composite flour (Adebayo, 2017). The incorporation of barley and soy flour in biscuits lowers the glycemic index of biscuits and it can be recommended to diabetic patients for maintaining blood glucose level (Kuar et al., 2017).

\section{Carbohydrate content}

Carbohydrate is the body's preferred energy source, and the most important fuel for the working muscle. During exercise of high intensity and brief duration, this nutrient provides most of the energy needs (Burke et al., 2004). Each gram of carbohydrate will produce 4 calories of energy and in the process will use 0.7 liters of oxygen. Carbohydrate content of food products depend on the type of ingredient used. Cereals are first and foremost a source of carbohydrates (McKevith, 2004). Carbohydrate content of biscuit produced from local rice variety and defatted soyabean blends decreased as the level of defatted soyabean incorporation increased (Eke- Ejiofor and Williams, 2016). According Hama et al. (2018) total carbohydrate content of biscuit formulated from millet and cowpea was decreased as the level of cowpea increased. Carbohydrate content of African yam bean flour and wheat composite biscuits were decreased as the incorporation level of African yam bean flour increased (Idowu, 2014). Malted sorghum has been reported to contain high levels of carbohydrate (Germah et al., 2011). The carbohydrate content of the malted sorghum soy biscuits decreased as the level of substitution with soy flour increased in the composite biscuits. The biscuit sample with $10 \%$ soy flour substitution had the highest (59.95\%) carbohydrate content while the sample with $40 \%$ soy flour substitution had the lowest (47.08\%) carbohydrate content (Bolarinwa et al., 2016). The carbohydrate content (47.08-59.95\%) of the malted sorghum-soy biscuits was however, lower than the carbohydrate content $(71.1274 .45 \%)$ of wheat cassava composite biscuits enriched with soy flour (Akinbowale, 2011). The variation in the carbohydrate content of the biscuits produced is due to differences in the composition of the composite flour. The decreased in carbohydrate of cereal and legume based biscuits could be due to low content of carbohydrate in the added legumes flour (Iwe, 2004). 
Table 1 : Nutrient Composition of Cereal and Legumes Based Biscuits

\begin{tabular}{|c|c|c|c|c|c|c|}
\hline Biscuit sample & Amount $(g / 100 g)$ & $\operatorname{Ash}(\%)$ & $\operatorname{Fat}(\%)$ & Protein $(\%)$ & $\begin{array}{l}\text { Fiber } \\
(\%)\end{array}$ & $\begin{array}{l}\text { Carbohydrate } \\
(\%)\end{array}$ \\
\hline Wheat & $100 \%$ & 1.42 & 2.28 & 11.22 & 3.54 & 75.22 \\
\hline Wheat-Soya & $40+60$ & 2.28 & 13.28 & 18.08 & 3.37 & 58.08 \\
\hline $\begin{array}{l}\text { Malted Sorghum and } \\
\text { Soyabean }\end{array}$ & $60+40$ & 2.81 & 30.79 & 11.74 & 3.46 & 47.08 \\
\hline $\begin{array}{l}\text { Lima bean, Sorghum, and } \\
\text { Wheat }\end{array}$ & $40+25+35$ & 3.25 & 3.56 & 19.33 & 4.36 & 62.09 \\
\hline Wheat-Chickpea & $75+25$ & 2.22 & 31.19 & 9.33 & 2.41 & 54.2 \\
\hline $\begin{array}{l}\text { Refined Wheat, Barley and } \\
\text { Chick pea }\end{array}$ & $25+50+25$ & 1.99 & 33.45 & 8.92 & 2.77 & 52.09 \\
\hline Millet and Cowpea & $70+30$ & 2.4 & 19.19 & 11.14 & 3.41 & 69.43 \\
\hline
\end{tabular}

Source: Okoye et al., 2008 ; Bolarinwa et al., 2016 ; Adebayo , 2017 ; Kuar et al., 2017; Hama et al., 2018.

\section{Ash Contents of Biscuits}

Minerals are essential substances for the musculoskeletal system as well as for numerous biological functions. For instance, insufficient supply of calcium and phosphate is normally associated with impaired skeletal development, and with increased incidences of bone and muscle injuries (Yannakoulia et al., 2004). The mineral content of malted sorghum-soy biscuits are varied depend on level of legumes used. The mineral content of the biscuits increased as the level of soy flour increased in the composite flour used to produce the biscuits. Because legumes have been reported to be good sources of ash Alabi et al. (2007) while malted sorghum and other cereal grains have been reported to have low levels of ash (Okoye et al., 2008). Soybean seeds have been reported to contain an appreciable quantity of minerals (Sanfu et al., 2010). Ash has been reported to be high in soy supplemented cereal meals (Alabi et al., 2007). Total mineral content of biscuit produced from local rice variety and defatted soyabean blends increased as the level of defatted soyabean incorporation increased (Eke- Ejiofor and Williams, 2016). Mineral content of African yam bean flour and wheat composite biscuits were also increased as the incorporation level of African yam bean flour increased (Idowu, 2014). Similar research report indicated that total mineral content of biscuits obtained from $40 \%$ of lima bean, $35 \%$ sorghum and $25 \%$ of wheat composite flour was higher than that of $100 \%$ wheat biscuits (Adebayo, 2017).

\section{Antinutrients}

\section{Phytic acid (PA)}

phytic acid is the primary storage compound of phosphorus in cereals, legumes, nuts, and oilseeds. It accounts for up to $90 \%$ of total phosphorous content and contributes as much as $1.5 \%$ to the seed dry weight (Lott et al., 2009). It's principal functions in seeds are the storage of phosphates as a source of energy and the antioxidant activity of the germinating seed (Raboy, 2003). The amount of PA in plants are very variable and, presumably, it depends on growing conditions and harvesting techniques (Coulibaly et al., 2011). Nevertheless, phosphorus in PA is mostly not bioavailable to monogastric animals, including humans, due to insufficient degradation capabilities in their gastrointestinal tract under the $\mathrm{pH}$ conditions of the small intestine (Coulibaly et al., 2011). The major concern about the presence of phytate in the diet is its negative effect on mineral uptake which makes bone mineral deficient. PA has the ability to chelate metal cations, primarily iron, zinc, calcium, as well as proteins and digestive enzymes, such as pepsin, amylase, and trypsin. The phytate content of the malted sorghum-soy composite biscuits decreased with increasing soy flour substitution. phytate content of biscuit produced from AYBF and wheat flour was decreased as the incorporation level of AYBF increased (Ihemeje et al., 2018). Related research report indicated the phytate content of biscuit produced from mung bean flour and wheat flour was increased as the incorporation level mung bean increased (Akaerue and Onwuka., 2010). This is due to significant quantity of phytic acid available in mung bean than wheat flour. Malting caused significant reduction phytate content in cereal and legumes. Phytate content of biscuit produced from lima bean and wheat composite flour was higher than that of sprouted lima bean biscuits (Adebayo, 2017). Malted sorghum flour with no soy flour substitution had the highest phytate content while the lowest value was observed in composite flour substituted with $40 \%$ soy flour (Bolarinwa et al., 2015). According to Idris et al. (2007) reduction of phytate content in malted cereal and legume ingredients could be due to activity of phytase enzyme, that reduce of phytate by degrading of phytate into inorganic phosphorus and myo inositol and its intermediate forms.

\section{Condensed Tannins}

Tannins are water-soluble phenolic compounds that have the ability to bind or precipitate proteins from aqueous solutions. They bind with storage proteins of both cereal and legumes thus caused inhibition of their digestibility. 
The anti-nutritional effect of tannins includes diminished growth rate, the bioavailability of mineral elements and decreased feed efficiency in rats, swine, poultry, and ruminants. The tannins reduced the availability of minerals, proteins, and starch of the sorghum (Barros et al., 2012). Interaction of tannins and other phenolic compounds with starch and effects on in vitro starch digestibility. Tannins from cereals and legumes cause reduction in digestibility and efficiency of mineral absorption. The presence of condensed tannins in cereal cultivars reduce protein digestibility (Duodu et al., 2003). Because they bind with proteins and inhibit enzymes (Scalbert et al., 2000).

Tannin content of biscuit produced from African yam bean flour and wheat flour was decreased as the incorporation level of AYBF increased (Ihemeje et al., 2018). This because of tannin content of AYBF was lower than that of wheat. Related research report showed that tannin content of biscuit produced from mung bean and wheat flour was at the safe level and increased as the incorporation level mung bean increased (Akaerue and Onwuka., 2010). According to Adebayo (2017) tannin content of biscuit produced from lima bean and wheat composite flour was higher than that sprouted lima bean biscuits. Tannin content (18.9-22.9\%) of the malted sorghum-soy composite biscuits reported by Bolarinwa et al., (2015) is lower than the tannin content (23.8-26.7\%) of sorghum cultivars reported by (Idris et al., 2005). Obviously, substitution of malted sorghum flour with soy flour resulted decreased in the level of tannin in the composite flour. Lower tannin content observed when different malted ingredient used in biscuit production could be due to degradation of tannin during malting.

\section{Sensory Qualities of Biscuits}

Color: It is very significant parameter in judging well baked biscuits. It reflect the suitable raw material used for the preparation and also provides information about the formulation and quality of the product (Mepba et al., 2007). With respect to color, biscuit prepared from refined wheat $(25 \%)$, oat $(50 \%)$ and chickpea $(25 \%)$ blends had significantly higher color values as compared with 100\% wheat flour (Kuar et al., 2017). Biscuit produced from local rice variety and defatted soyabean blends was in acceptable ranges upto $20 \%$ defatted soyabean incorporation levels with respect to color (Eke- Ejiofor and Williams, 2016). Color score of biscuit produced from local lima bean, sorghum and wheat blends was increased as lima bean incorporation increased (Adebayo, 2017). Color score of biscuit produced from AYBF and wheat composite flour was decreased as the proportion of wheat decreased (Idowu, 2014). Similar research study report indicated that color sensory score of biscuit formulated from millet and cowpea was increased as the level of cowpea increased (Hama et al., 2018).

The complementation of soya flour to malted sorghum up to $40 \%$ shows significant difference with respect to color attributes when compared to the $100 \%$ wheat biscuit (Bolarinwa et al., 2016). The other related research output indicated that complementation of chickpea flour up to $20 \%$ to wheat flour was acceptable with respected to color when compared to the $100 \%$ wheat biscuit (Yohannes, 2014). Siddiqui et al. (2003) found that the biscuits color is related to the high level of proteins. Biscuits color becomes darker with increasing the levels of proteins in the formulation due to the amino acids of proteins react with reducing sugars during baking in the Maillard reaction (Iwe, 2007; Ubbor and Akobundu, 2009).

Aroma : The mean aroma score of the food product is significantly affected by blend proportion. Aroma score of biscuit formulated from millet and cowpea was decreased as the level of cowpea complementation increased (Hama et al., 2018). This could be due beany flavor of legume crops. Related research finding showed that Aroma scores of biscuit produced from local rice variety and defatted soyabean blends was decreased as defatted soyabean incorporation increased (Eke-Ejiofor and Williams, 2016). According to Adebayo (2017) Aroma scores of biscuit produced from local lima bean, sorghum and wheat blends was decreased as lima bean incorporation increased. Biscuit produced from $40 \% \mathrm{AYBF}$ and $60 \%$ of wheat composite flour was similar with respect to aroma as compared to $100 \%$ wheat biscuits (Idowu, 2014).

Aroma of biscuit produced from $25 \%$ refined wheat flour, $50 \%$ barley and $25 \%$ soya flour was better than biscuit produced from 100\% wheat flour (Kuar et al., 2017). Sensory score of biscuit produced from sorghum soya based composite flour with respect to aroma decreased as the level of soya flour addition increased when compared to $100 \%$ malted sorghum biscuits (Bolarinwa et al., 2016). Similar research finding reported by Yohannes, (2014) showed that complementation of chickpea flour up to $20 \%$ shows no significant difference with respect to aroma when compared to $100 \%$ wheat biscuit. Hence $20 \%$ chickpea flour addition was acceptable with respect to aroma. Aroma of cereal legume based snack food can be improved using traditional processing techniques such as soaking, malting, fermentation, boiling, etc.

Taste: Taste is the primary factor that determines the acceptability of any product which has the highest impact as far as market success of product is concerned. The taste of biscuits produced from sprouted lima bean, sprouted sorghum and wheat flour were favorably compared with the (100\%) wheat biscuits (Adebayo et al., 2017). According Bolarinwa et al. (2016) the biscuit with 60\% malted sorghum and 40\% soybean flour had the best score for sweetness. Similar research reports indicated the mean taste score of chick pea flour supplementation up to $20 \%$ showed no significant different as compared to $100 \%$ wheat biscuits.

Texture: It is fundamentally important in determining the consumer acceptability of biscuit (Pareyt and Delcour, 
2008). The biscuit made from $60 \%$ malted sorghum and $40 \%$ soybean flour had the best score for texture (Bolarinwa et al., 2016). However, biscuits made by high level of pigeon pea addition to cereals resulted in harder texture (Tiwari et al., 2011). Complementation of chickpea flour up to 15\% showed no significant difference in terms of texture when compared to $100 \%$ wheat biscuit (Yohannes, 2014). The other research finding showed that the crispness of biscuits decreased with reduction level of sprouted lima bean substitution to sprouted sorghum and wheat flour as compared to control sample 100\% wheat biscuits (Adebayo et al., 2017). Texture of biscuit produced from local rice variety and defatted soyabean blends was in acceptable ranges upto $30 \%$ defatted soyabean incorporation levels (Eke- Ejiofor and Williams, 2016).

Texture score of biscuit produced from $25 \%$ refined wheat flour, $50 \%$ barley and $25 \%$ soya flour was similar with biscuit produced from 100\% wheat flour (Kuar et al., 2017). However, mean sensory scores of texture of biscuit produced from $50 \%$ refined wheat flour, $25 \%$ barley and $25 \%$ chickpea flour was higher than biscuit produced from 100\% wheat flour (Kuar et al., 2017). Texture score of biscuit produced from AYBF and wheat composite flour was increased as the proportion of AYBF incorporation increased (Idowu, 2014). According to Hama et al. (2018) texture score of biscuit formulated from millet and cowpea was higher than that of 100\% millet biscuits.

Overall acceptability: The biscuit sample made from 20\% AYBF and $80 \%$ wheat flour showed no significant difference with the $100 \%$ wheat biscuit for the overall acceptability (Idowu, 2014). The substitution of wheat flour (WF) with soybean flour (SF) upto $60 \%$ in biscuit production generate good results in sensory acceptability (Okoye et al., 2008). Based on individual rating, biscuit sample made from (60\% malted sorghum and $40 \%$ soybean flour) was most preferred in terms of overall acceptability (Bolarinwa et al., 2016). Over all acceptability of biscuit produced from local lima bean, sorghum and wheat blends was decreased as lima bean incorporation increased (Adebayo, 2017). Over all acceptability of biscuit produced from local rice variety and defatted soyabean blends was in acceptable ranges upto 30\% defatted soyabean incorporation levels (Eke- Ejiofor and Williams, 2016). Related research finding showed overall acceptability of biscuit produced from $25 \%$ refined wheat flour, $50 \%$ barley and $25 \%$ soya flour was equally preferred by panelists with biscuit produced from $100 \%$ wheat flour(Kuar et al., 2017). Overall acceptability of biscuit formulated from millet and cowpea was decreased as the level of cowpea increased (Hama et al., 2018). Similar research reports indicated that the overall acceptability of biscuit produced from chickpea and wheat blends decreased as the level of chickpea addition increased. But the mean score of overall acceptability up to $20 \%$ chickpea flour incorporation was not significantly different when compared to control biscuit (100\% wheat) (Yohannes, 2014).

\section{CONCLUSION}

Nutrient composition of cereals improved when fortified with legumes. Soybean, chickpea, cowpea, lima bean, and African yam bean flour are the most important nutritious among leguminous crops used partially to complement cereal in the production of biscuits which is nutritionally superior and organoleptically acceptable. Biscuits produced from mixture of different flours of cereals and legumes can satisfy specific functional characteristics and nutrients composition. Protein, ash and crude fiber content of biscuit produced from lima bean, sorghum and wheat composite flour were highest as compared to other biscuits. Highest fat content was obtained from biscuits produced from refined wheat, barley and chickpea flour. Carbohydrate content of biscuit produced from $100 \%$ wheat flour was highest as compared to some other cereal and legume blend biscuits. Since some cereal and legume based biscuits have an appreciable amount of protein, fat, carbohydrate and micronutrients then, the consumption of the biscuits are advisable to combat protein energy malnutrition and micronutrient deficiency. Malting is easily applicable processing techniques and will be used to reduce antinutrients in various grain to safe level. It is effective processing techniques to enhance the nutritional status, flavor profile, color attributes an improvement in protein and starch digestibility of cereal -legumes based food. Biscuits produced from malted ingredient of some cereal and legume based achieved acceptable in terms of sensory attributes and safe level in tannin and phytic acid antinutrients.

\section{REFERENCE}

Adebayo, S.F. and Okoli, E.C. 2017. Production and Evaluation of Biscuits from Lima Bean (Phaseolus Lunatus), Sorghum and Wheat Flour Blends. Journal of Environmental Science, Toxicology and Food Technology, Volume 11, PP 44-48

Adebowale, A.A., Adegoke, M.T., Sanni, S.A., Adegunwa, M.O. and Fetuga, G.O. 2012. Functional properties and biscuit making potentials of sorghum-wheat flour composite. American J. Food Technology, 7(6): 372379.

Akaerue, B.I. and Onwuka, G.I. 2010. Mung bean (Vigna radiata (l) wilczek) flour in biscuit making: effect on proximate composition. In 34th Annual Conference of Nigerian institute of Food Science and Technology; Port Harcourt, Nigeria

Akinbowale, O.F. 2011. Physico chemical and Sensory properties of wheat-cassava composite biscuit enriched with soy flour. African J. Food Science, 5(2):50-56. 
Akpapunam, M.A., Badifu, G. and Etokudo, E.P. 1997. Production and quality characteristics of Nigerian Agidi supplemented with soy flour. Journal of Food Science and Technology, 34 : 143-145.

Alabi, M.O. and Anuonye, J.C. 2007. Nutritional sensory attributes of soy supplemented cereal meals. Nigeria Food Journal, 25(1) : 100-110.

Alobo, A.P. 2001. Effect of Sesame Seed flour on millet biscuit characteristics. Plant Food Human nutrition, 56 : 195- 200.

Andersen, L.L., Tufekovic, G. and Zebis, M. K. 2005. The effect of resistance training combined with timed ingestion of protein on muscle fiber size and muscle strength metabolism, 54(2): 151-156.

Ayo, J.A., Nkama, I. and Adewori, R. 2007. Physical, In-vitro digestibility and organoleptic evaluation of Acha wheat biscuit supplemented with soybean flour. Nigeria Food Journal, 25:77- 83.

Ayo, J.A., Ayo, V.A., Popoola, C., Omosebi, M., Joseph, L. 2014. Production and evaluation of malted soybeanacha composite flour bread biscuit. African J. Food Sci. Technology, 5(1):21-28.

Barros, F., Awika, J.M. and Rooney, L.W. 2012. Interaction of tannins and other sorghum phenolic compounds with starch and effects on in vitro starch digestibility. Journal of Agriculture and Food Chemistry, 60 : 11609 11617.

Bermink, M.R. and Nielson, S.S. 1994. Introduction to the Chemical Analysis of Foods, pp 169-180, Jones and Bartlett Publishers, Boston.

Biglari, F., Alkarkhi, A.F.M. and Easa, A.M. 2008. Antioxidant activity and phenolic content of various date palm (Phoenix dactilifera) fruits from Iran. Journal of Food Chemistry, 107: 1636-1641.

Bolarinwa, I.F., Olaniyan, S.A., Adebayo, L.O. and Ademola, A.A. 2015. Malted sorghum-soy composite flour: Preparation, chemical and physicochemical properties. J. Food Process Technology 6(8) : 1-7.

Bolarinwa, I.F, Abioye, A.O., Adeyanju, J.A. and Kareem, Z.O. 2016. Production and Quality Evaluation Of Biscuits Produced From Malted Sorghum-Soy Flour Blends. Journal of Advances In Food Science and Technology, 3(3) : 107-113.

Brigas, D.E., Hough, R. and Young,T.N. 2003. Malting and Brewing Science Malt and Sweet wort. 2ndEdn.Chapman and Hall, UK.p.295-296.

Burke, L.M., Kiens, B. and Ivy, J.L. 2004. Carbohydrates and fat for training and recovery Journal of Sport Science, $22(1): 15-30$

Cleaveland, L.E., Moshfegh, A.J. and Albertson, A.M. 2000. Dietary intake of whole grains. Journal of the American College of Nutrition, 19: 331S-338S.

Coulibaly, A., Kouakou, B. and Chen, J. 2011. Phytic Acid in Cereal Grains: Structure, Healthy or Harmful Ways to Reduce Phytic Acid in Cereal Grains and Their Effects on Nutritional Quality. Am. J. Plant Fertil. Technology, 1: 1-22

CSA (Central Statistics Agency for Ethiopia ). 2015. Ethiopian crop and livestock Survey reports. Addis Ababa, Ethiopia

Dendy, D.V. 1995. Sorghum and Millets Chemistry and Technology. St Paul, MN: AmericanAssociation of Cereal Chemists, 1995:69-124.

Dewar, J. Taylor, J.R.N. and Berjak, P. 1997. Effects of germination conditions with optimized steeping on sorghum malt quality with particular reference to free amino nitrogen. Journal of the Institute of Brewing, 103: $171-175$

Dhingra, S. and Jood, S. 2000. Organoleptic and Nutrition Evaluation of wheat breads supplemented with soybean and barley flour. Food Chemistry 77: 479-488.

Dicko, M.H., Gruppen, H., Traoré, A.S., Voragen, A.G. and van Berkel, W.J. 2006. Sorghum grain as human food in Africa. relevance of the content of starch and amylase activities. Afr J Biotech, 5(5): 384-395.

Duodu, K.G., Taylor, J.R.N., Belton, P.S. and Hamaker, B.R. 2003. Factors affecting sorghum protein digestibility. J Cereal Sci., 38(2) : 117-131.

Edema, M.O., Sanni, L.O. and Sanni, A.I. 2005. Evaluation of maize-soybean flour blends for sour maize bread production in Nigeria. Afri Journal of Biotechnology, 4: 911-918.

Eke- Ejiofor, J. and Williams, L. 2016. Evaluation of Defatted soybean flour Inclusion on the properties of Rice based Biscuits. International Journal of Biotechnology and Food Science Vol. 4(4), pp. 63-71

Eneche, E.H. 1999. Biscuit making potentials of millets-pigeon pea flour blends. Plant foods Human Nutrition, 54 : 21-27.

Eneche, H.E. 2003. Preparation and physico-chemical properties of flours and protein concentrates of raw and germinated African yam bean (Sphenostylis stenocarpa) seeds. In 34th Annual Conference and Scientific meeting of Nutrition society of Nigeria

Falola, A.O., Olatidoye, O.P., Balogun, I.O. and Opeifa, A.O. 2013. Evaluation of nutritional, physicochemical properties and acceptability of un-dehulled 'ofada' rice and soy bean flour blends. Journal of Agriculture and Veterinary Science, 5: 118-128.

Famurewa Jav, Raji, A.O. 2005. Parameters affecting milling qualities of undefeated soybeans. Inter J Food Eng 
$1: 6$.

Filipcev, B., Šimurina, O., Sakac, M., Sedej, I., Jovanov, P., Pestoric, M. and Bodroža Solarov, M. 2011. Feasibility of use of buckwheat flour as an ingredient in ginger nut biscuit formulation. Food Chemistry, 125(1): 164-170.

Gernah, D.I, Ariahu, C.C. and Ingbian, E.K. 2011. Effect of malting and lactic fermentation on some chemical and function properties of maize (Zea mays). American J. Food Technology, 6(5): 404-412.

Hama. B. F., Ouattara. F., Savadogo. A. Simpore. M. and Diawara. B. 2018. Study of the Nutritional Quality and Acceptability of Millet Biscuits (Pennissetum glaucumL.) Supplemented with Cowpea (Vigna unguiculataL.) and Bambara Groundnut (Vigna subterranea L.). Journal of Agricultural Science and Food Research, 9:1

Hooda,S. and Jood, S. 2005. Organoleptic and nutritional evaluation of wheat biscuits supplemented with untreated and treated fenugreek flour. Food Chernistry, 90: 427 - 435.

Hoseney, R.C. 1994. Principles of cereal science and Technology. Second edition, St. Paul: American Association of cereal chemistry, 16-19.

Idowu, A.O. 2014. Development, nutrient composition and sensory properties of biscuits produced from composite flour of wheat and African yam bean. British Journal of Applied Science and Technology, 4(13), 1925

Idris, H.W., Hassan, A.D., Babiker, E.E. and Eitinay, A.H. 2005. Effect of malt-pretreatment on anti-nutritional factors and $\mathrm{Hcl}$ extractability of minerals of sorghum cultivars. Pakistan Journal of Nutrition, 4: 396-401.

Idris, W.H., AbdelRahaman, S.M., Elmaki, H.B., Babikar, E.E. and Eltinay, A.H. 2007. Effect Of malt pretreatment on HCL extractability of calcium, phosphorus, and iron of sorghum(Sorghum bicolor) cultivars. International Journal of Food Science and Technology, 42: 194-199.

Ihemeje, A., Nwanekezi, E.C., Odimegwu, E.N. and Ekwe, C.C. 2018. Effect of processing methods of toasting, soaking, boiling, sprouting on dietary fibre and antinutrient contents of african yam bean and red kidney bean flour. European Journal of Food Science and Technology, Vol.6, No.1, pp .40-48.

Itagi, H. N. and Singh, V. 2012. Preparation, nutritional composition, functional properties and antioxidant activities of multigrain composite mixes. Journal of food science and technology , 49(1): 74-81

Iwe, M.O. 2007. Current Trends in Sensory Evaluation of Foods. Rejoint Communication Services Ltd, Uwani Enugu, Nigeria, 46-47.

Kaur, K.D., Jha, A., Sabikhi, L. and Singh, A.K. 2011. Significance of coarse cereals in health and nutrition: a review. Journal of Food Science and Technology, 1-13.

Kaur, K., Kaur, H., \& Bains, K. 2017. Development and Nutritional Evaluation of Cereal and Pulse Based Biscuits for Diabetic Patients. British Journal of Applied Science and Technology, 21(5): 1-8.

Kushi, L.H., Meyer, K.A. and Jacobs, D.R. 1999. Cereal, legume and chronic diseases risk reduction: Evidence from epidemiologic studies. American Journal of Clinical Nutrition, 70:451-458.

Lee, B.H., Carr, T.P., Weller, C.L., Cuppett, S., Dweikat, I.M. and Schlegel, V. 2014. Grain sorghum whole kernel oil lowers plasma and liver cholesterol in male hamsters with minimal wax involvement. Journal of Functional Foods. 7 : 709-718.

Liu, K.S. 1997. Chemistry and Nurtitional Value of Soybean Components. In Soybean: Chemistry, Technology, and Utilization, Chapman \& Hall, New York, pp. 25-113.

Lott, J.N.A., Bojarski, M., Kolasa, J., Batten, G.D. and Campbell, L.C. 2009. A review of the phosphorus content of dry cereal and legume crops of the world. Int. J. Agr. Resour. Govern. Eco, 8:351-370

Machado, C.M., Ferruzi, M.G. and Nielsen, S.S. 2008. Impact of the hard-to-cook phenomenon on phenolic antioxidants in dry beans (Phaseolus vulgaris). Journal of Agriculture and Food Chemistry, 56:3102-3110.

Maidala, Dahuwa, T.N. and Bakoshi. 2016. Effect of Different Malting Periods on Anti nutritional Factors of Three Locally Grown Sorghum Varieties in Bauchi State, Nigeria . International Journal of Chemistry and Chemical Processes Vol. 2 No.1 www.iiardpub.org

McKevith, B. 2004. Nutritional aspects of cereals. Nutr. Bull, 29 (2) : 111-142.

Mepba, H.D., Eboh, L. and Nwaojigwa, S.U. 2007. Chemical composition, functional and baking properties of wheat-plantain composite flours. African Journal of Food Agriculture Nutrition and Development, 7(1): 122

Murekatete, N., Hua,Y.F. and Irakoze, P.C. 2010. Characterization of ready-to-eat composite porridge flours made by soy-maize-sorghum wheat extrusion cooking process. Pakistan J. Nutr, 9(2): 171-178.

Ndife, J. Kida, F. and Fagbemi, S. 2014. Production and quality assessment of enriched cookies from whole wheat and full fat soya. Europe J Food Science and Technology, 2: 19-28.

Neelam, K. and Rajni, G. 2009. Effect of composite flour fortification to wheat flour on the quality characteristics of unleavened bread. British Food J, 11(6):554-564.

Okaka, J.C.1997. Biscuit manufacture in cereals and legumes storage and processing technology. Data and Microsystems Publishers Ltd Enugu, 115-130.

Okalebo, J. 2013. Preliminary Participatory On-farm Sorghum Variety Selection for Tolerance to drought, Soil Acidity and Striga in Western Kenya. Maina Moi University, Kenya First Bio-Innovate Regional Scientific 
Conference United Nations Conference Centre (UNCC-ECA) Addis Ababa, Ethiopia.

Okoye, J.I, Nkwocha, A.C. and Ogbonnaya, A.E. 2008. Production, proximate composition and consumer acceptability of biscuits from wheatsoybean flour blends. Continental J. of Food Science and Technology, 2: 6-13.

Okpala, L.C. and Okoli, E.C. 2011. Nutritional evaluation cookies produced from pigeon pea flour, cocoyam flour and sorghum flour blends. African J. Biotechnology, 10(3): 433-438.

Olaoye, O.A, Onilade, A.A. and Idowu, O.A. 2006. Quality characteristics of bread produced from Composite flour of wheat, plantain and soybeans. Afr J Biotechnology, 5: 1102-1106.

Pareyt, B. and Delcour, J.A. 2008. The Role of Wheat Flour Constituents, Sugar, and Fat in Low Moisture Cereal Based Products: A Review on Sugar-Snap Cookies. Critical Reviews in Food Science and Nutrition, 48 (9): 824-839.

Raboy, V. 2003. Myo-Inositol-1,2,3,4,5,6-hexakisphosphate. Phytochemistry, 64 : 1033-1043

Rave, K., Roggen, K., Dellweg, S., Heise, T., and Tom Dieck, H. 2007. Improvement of insulin resistance after diet with a whole-grain based dietary product: results of a randomized, controlled cross-over study in obese subjects with elevated fasting blood glucose. British Journal of Nutrition, 98(5), 929-936

Rita, E.S. and Sophia, D. 2010. Utilization of soy bean flour in the production of bread. Pakistan Journal of Nutrition, 9: 815-818.

Rooney, L.W. and Waniska, R.D. 2000. Sorghum food and industrial utilization. pp.689-729. In: C.W. Smith and R.A. Frederkisen, (eds). 'Sorghhum: Origin, History, Technology, and Production, John Wiley and Sons, New York. .

Salunke, B.K., Kotkar, H.M., Mendki, P.S., Upasani, S. M. and Maheshwari, V.L. 2005. Efficacy of flavonoids in controlling Callosobruchuschinensis (L.) (Coleoptera: Bruchidae), a post-harvest pest of grain legumes. Crop Protection , 24(10):888-893.

Sandberg, A.S. and Andlid, T. 2002. Phytogenic and microbial phytases in human nutrition. International Journal of Food Science and Technology, 37, 823-833.

Sanfu, R.E. and Darko S. 2010. Utilization of soybean flour in the production of bread. Pakistan J. Nutr, 9(8) : $815-818$

Sanni, S.A., Adebowale, A.A., Olayiwola, I.O. and Maziya, D. 2008. Chemical composition and pasting properties of iron fortified maize flour. J Food Agric Environment, 6:172-175.

Scalbert, A., Deprez, S., Mila, I., Albrecht, A., Huneau, J. and Rabot, S. 2000. Proanthocyanidins and human health: Systemic effects and local effects in the gut. BioFactor, 13: 115-120.

Schneeman, B.O. 2002. Gastrointestinal physiology and functions. Bristish J. Nutrition, 88(2): 159-163.

Siddiqui, N.R., Hassan, M., Raza, S., Hameed, L. and Khalil, S. 2003. Sensory and physical evaluation of biscuits supplemented with soy flour. Pakistan Journal of Food Science. 13(1-2): 45- 48.

Svec, I. and Hruskova, M. 2010. Evaluation of wheat bread features, Journal of Food Engineering, 99(4) : 505510.

Taha, M.R., Majdi, A.A. and Khalil, I.E. 2006. Effect of Chickpea, Broad Bean, or Isolated Soy Protein Additions on the Physicochemical and Sensory Properties of Biscuits. Journal of Food Science, 71(6) : 438-442.

Thompson, F.E., Midthune, D. and Subar, A.F. 2004. Performance of a short tool to assess dietary intakes of fruits and vegetables, percentage energy from fat and fibre. Public Health Nutrition, 7(8) : 1097-105.

Tiwari, B.K., Brennan, C.S., Jaganmohan, R., Surabi, A. and Alagusundaram, K. 2011. Utilisation of pigeon pea (Cajanus cajan L) by products in biscuit manufacture. LWT - Food Science and Technology, 44: 1533-1537.

Tovar, J., Bjorck, I.M. and Asp, N.G. 1992. Incomplete digestion of legume starches in rats: A study of precooked flows containing retrograded and physically inaccessible starch fractions. Journal of Nutrition, 122: 1500-7.

Ubbor, S.C. and Akobundu, E.N.T. 2009. Quality Characteristics of Cookies from Composite Flours of Watermelon Seed, Cassava and Wheat. Pakistan Journal of Nutrition. 8 (7): 1097-1102.

Ugwu, F.M. and Oranye, N.A. 2006. Effects of some processing methods on the toxic components of African breadfruit (Treculia africana). African Journal of Biotechnology, 5 : 2329-2333.

Wardlaw, G.M. 2004. Perspectives in nutrition (6th ed.). McGram Hill Companies, New York, U.S.A.

Willett, W., Manson, J.A. and Liu, S. 2002. Glycemic index, glycemic load, and risk of type II diabetes. American Journal of Clinical Nutrition, 76: 274-280.

Yadav, D.N., Thakur, N. and Sunooj, K.V. 2012. Effect of partially de-oiled peanut meal flour (DPMF) on the nutritional, textural, organoleptic and physicochemical properties of biscuits. Food and Nutrition Science, 3: 471-476.

Yannakoulia, M. Keramopoulos, A. and Matalas, A.L. 2004. Bone mineral density in young active females: the case of dancers. International Journal of Sport Nutrition Exercise metabolism, 14(3): 285-97

Yohannes Tolesa . 2014. Development of Value Added Bread and Biscuits Supplemented with Chickpea Flour. MSc Thesis, Addis Ababa University, Addis Ababa. 52-53 pp. 